
ISSN 2328-3548

\title{
International Journal of Stem Cell Research and Transplantation: Perspectives on its Accomplishments
}

Editorial

Shrestha BM

Division of Renal Transplantation, Sheffield Kidney Institute, Northern General Hospital, Herries Road, Sheffield, UK.

It has been a great honour and privilege for me to be associated with International Journal of Stem Cell Research and Transplantation (IJST) in the capacity of an Editorial Board Member and be able to overview the success accomplished by the IJST over the past 3 years. Establishing any scientific journal from its stage of infancy to a level of universal recognition after going through transitional phases, particularly in the current climate of heavy competition existing between several well-established scientific journals, is a major challenge. Research on stem cells and organ transplantation have rapidly advanced over the last three decades to address complex medical conditions which are not amenable to conventional modalities of treatment. Being able to consolidate important information on the subjects and deliver effectively to the scientific community is the ultimate goal of IJST.

Since the inception of IJST in March 2013, 26 issues have been published up to date, which is a commendable successon its own right, which reflects its popularity among the researchers in the field of stem cell and organ transplantation. The type of published manuscripts in the IJST included research articles $(53 \%)$, reviews $(21 \%)$, editorials $(17 \%)$, case reports $(4.5 \%)$ and research communications $(4.5 \%)$. Of these, majority ( $93 \%)$ were related to stem cell research.

The median time to publication from the day of acceptance of the manuscript was 3 days (range, 1-26 days). Similarly, the median time to publication from the date of submission was 27 days (range, 1-145 days). Importantly, the short article processing time reflects the commitments of the whole management team of SciDoc Publishers and the members of the Editorial team for making the novel research works available to the scientific community at the earliest possible time. The IJST has a robust Editorial board which is represented by eminent scholars from all over the world with their major interests in stem cell research and organ transplantation, which itself is a matter of great feat.

The published articles encompassed important aspects of ongoing research on stem cells and organ transplantation, in both experimental and human clinical settings [1]. All articles represented high qual- ity research works, which provided succinct and novel information to the readers. They were submitted by eminent scientists from prestigious academic institutions across the globe.

I have had opportunities to write editorials and a review for the IJST, which I enjoyed very much, particularly the prompt responses I had received from the editorial board and publication team, which was very encouraging [2-4]. I liked the lay out of the journal, which looked not only attractive, but also easy to read. The editing of the manuscripts prior to their publication was very thorough and accurate. IJST is an open-access journal and has ensured accessibility of all published articles to the readers worldwide without having to pay any charges for accessing the articles, which is a commendable service delivered by the SciDoc Publishers.

Currently, the IJST is indexed in Google Scholar, Cross-Reference, Index Copernicus, Pubshub, ICMJE and J-Gate and has achieved an Impact Factor of 1.316. I am confident that IJST will be indexed in PubMed very shortly because of its high-quality contributions to the scientific community, which will attract and encourage more academicians to submit their scientific works for publication in the IJST. Clearly, the success of any journal relies upon the confidence and trust of the authors and the readers on the journal, and I am convinced that IJST has already crossed that barrier and destined to succeed in achieving its long cherished goal.

\section{References}

[1]. El Garem NH, Amin MA, Metwalli HG, El Shenawy IG, Hussien MA (2016) Autologous Bone Marrow-Derived Stem Cell Transplantation in Patients With Child C Liver Cirrhosis Comparative Study. Int J Stem Cell Res Transplant. 4(8): 228-234.

[2]. Shrestha BM (2016) Renal Transplantation from Donation After Circulatory Death Donors: Evolution of Strategies. Int J Stem Cell Res Transplant. 04(2): 1-3.

[3]. Shrestha BM (2016) Living Kidney Donation: Evolution of Strategies. Int J Stem Cell Res Transplant. 04(1e): 1-2.

[4]. Kumar A, Shrestha BM (2016) Evolution of Immunosuppressive Agents in Renal Transplantation: An Updated Review. Int J Stem Cell Res Transplant. 04(3): 158-172.

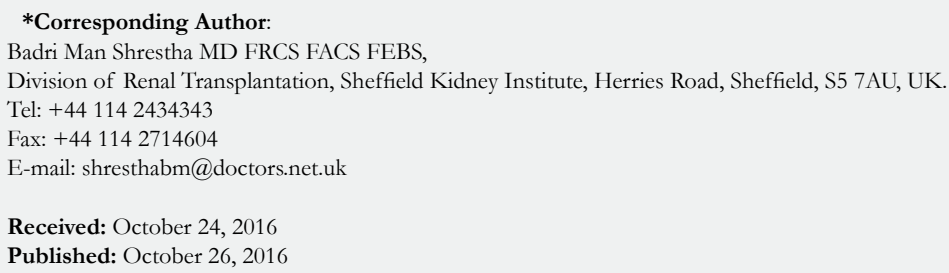

Copyright: Shrestha $\mathbf{B M}^{\circ}$ 2016. This is an open-access article distributed under the terms of the Creative Commons Attribution License, which permits unrestricted use, distribution and reproduction in any medium, provided the original author and source are credited. 